\title{
KARAKTERISASI BIOPLASTIK BERBAHAN KOLANG-KALING DENGAN MONOGLISERIDA DARI MINYAK KELAPA
}

\author{
Sri Sutanti* Cicilia Kusuma Dewi \\ Teknik Kimia, Politeknik Katolik Mangunwijaya \\ "Email : butanti10@gmail.com
}

\begin{abstract}
Abstrak
Bioplastik merupakan plastik yang dapat diperbaharui karena terbuat dari bahan alam yang bersifat ramah lingkungan dan sumbernya melimpah di alam. Salah satu bahan alam yang dapat digunakan untuk pembuatan bioplastik adalah kolang-kaling. Penelitian ini bertujuan mempelajari pengaruh penambahan monogliserida terhadap karakteristik bioplastik dari kolang-kaling. Variabel bebas pada penelitian ini yaitu jumlah monogliserida yang ditambahkan (0\%; 1\%; 2\%; 3\%; 4\%; dan 5\%). Proses pembuatan bioplastik dari kolang-kaling pada penelitian ini terdiri dari 2 tahap proses, yaitu: pertama adalah proses pembuatan monogliserida dari $100 \mathrm{~g}$ minyak kelapa "Barco" dengan $190 \mathrm{~g}$ gliserol dan katalis $\mathrm{NaOH}$ sebanyak 0,1\% dari jumlah minyak. Pembuatan monogliserida dilakukan pada temperatur $200^{\circ} \mathrm{C}$ selama 3 jam disertai pengadukan. Monogliserida hasil reaksi dipisahkan menggunakan corong pisah. Tahap ke dua yaitu proses pembuatan bioplastik dari kolang-kaling. Sebanyak 30 $g$ bubur kolang-kaling ditambahkan aquasdest $70 \mathrm{~g}$, dan dilakukan proses gelatinasi pada temperatur $70^{\circ} \mathrm{C}$. Selanjutnya ditambahkan monogliserida dan diaduk selama 15 menit pada temperatur $70^{\circ} \mathrm{C}$. Sebelum adonan bioplastik dituang ke cetakan, dilakukan proses degassing selama 10 menit. Film bioplastik didinginkan dalam oven pada temperatur $55^{\circ} \mathrm{C}$. Karakteristik bioplastik ditinjau dari ketebalan, densitas, tensile strength, elongation dan morfologinya.
\end{abstract}

Kata kunci: Bioplastik, Karakteristik, Kolang-kaling, Monogliserida

\section{PENDAHULUAN}

Plastik merupakan salah satu bahan pengemas yang selalu dibutuhkan dan diminati banyak orang. Kebutuhan akan plastik semakin meningkat dari waktu ke waktu. Menurut Darni, dkk., (2010) kebutuhan plastik masyarakat Indonesia tahun 2002 sekitar 1,9 juta ton kemudian meningkat menjadi 2,1 juta ton di tahun 2003 dan di tahun 2004 meningkat lagi menjadi 2,3 juta ton. Hal ini karena sifat fleksibel plastik yang ringan, kuat, tahan air, dan harganya yang terjangkau.

Tujuan dari pengemasan adalah untuk mencegah atau mengurangi kerusakan, melindungi bahan dari gesekan, dan benturan. Di samping itu pengemasan juga berfungsi sebagai wadah agar bahan yang dikemas mempunyai bentuk yang memudahkan dalam penyimpanan, pengangkutan dan pendistribusiannya. Dari segi promosi, pengemas dapat berfungsi sebagai daya tarik pembeli (Syarief et al. 1988).

Gennadios and Weller, (1990) menjelaskan bahwa bioplastik dapat memberikan penahanan terhadap perpindahan panas, uap air dan bahan terlarut serta dapat menjadi pelindung terhadap kerusakan mekanis. Sedangkan dalam Lin and Zhao, (2007) disampaikan bahwa bioplastik dapat digunakan sebagai bahan pengemas untuk menjaga / mempertahankan kesegaran dan keamanan makanan. Bioplastik dapat mengalami biodegradasi sehingga bersifat ramah lingkungan.

Bioplastik merupakan plastik yang dapat diperbaharui karena senyawa senyawa penyusunnya berasal dari tanaman seperti pati, selulosa, dan lignin serta hewan seperti kasein, protein dan lipid. Menurut Danhowe and Fennema, (1994), komponen utama penyusun bioplastik dikelompokkan menjadi tiga, yaitu hidrokoloid, lipida, dan komposit. Hidrokoloid dapat berupa protein (kolagen, gelatin, protein kacang kedelai, corn zein, dan wheat gluten) atau polisakarida serta turunannya. Kelompok lipida terdiri dari lilin/wax, trigliserida, monogliserida terasetilasi, asam lemak, alkohol asam lemak dan ester sukrosa asam lemak.

Tak banyak dari jutaan plastik yang digunakan berbahan ramah lingkungan atau disebut dengan bioplastik, kebanyakan plastik yang beredar di masyarakat saat ini adalah plastik sintetik yang terbuat dari bahan minyak bumi. Plastik sintetik ini jelas tidak ramah lingkungan karena sulit terurai, tidak seperti bioplastik yang mudah terurai. Selain itu dilihat dari ketersediaan bahannya, plastik sintetik terbuat dari minyak bumi yang tidak dapat 
diperbarui, sedangkan bioplastik terbuat dari bahan alam yang sumbernya melimpah di alam.

Salah satu sumber daya alam yang dapat digunakan sebagai bahan dasar pembuatan bioplastik adalah kolang-kaling. Menurut Mahmud dan Amrizal (1991), kolang kaling mengandung pati sekitar 3,39\% dari berat buah. Dengan demikian kolang-kaling dapat digunakan sebagai bahan baku bioplastik kategori hidrokoloid. Keunggulan kolang-kaling jika digunakan sebagai sumber bahan baku bioplastik adalah ketersediaannya sepanjang tahun, mudah didapat, harga relatif murah dan secara ekonomis bernilai rendah karena kolang kaling hanya dimanfaatkan pada bulan Ramadan sebagai menu buka puasa.

Monogliserida merupakan komponen lipid yang diperoleh dari proses alkoholisis dari minyak nabati (trigliserida) dengan gliserol. Berdasarkan jenis substratnya, monogliserida dapat dihasilkan melalui reaksi esterifikasi langsung antara asam lemak dengan gliserol, reaksi transesterifikasi trigliserida dengan gliserol, reaksi transesterifikasi metil ester asam lemak dengan gliserol, reaksi hidrolisis trigliserida atau lemak dilanjutkan reaksi kondensasi asam lemak dengan gliserol atau dengan senyawa-senyawa turunannya. Keunggulan dari monogliserida selain sebagai lipid, kandungan gliserolnya dapat berperan sebagai plastisizer bioplastik. Plastisizer berfungsi untuk meningkatkan flesibilitas, sehingga bioplastik yang dihasilkan tidak rapuh, dan tidak mudah sobek.

Sejauh yang kami pelajari, belum kami dapatkan penelitian yang membahas tentang pengaruh monogliserida terhadap karakteristik bioplastik dari kolang-kaling.

\section{METODOLOGI}

Penelitian ini dilakukan di Laboratorium Kimia Organik Akademi Kimia Industri Santo Paulus Semarang dan dirancang dengan metode analisa deskriptif.

\subsection{Bahan}

Bahan yang dibutuhkan untuk proses penelitian ini meliputi: kolang kaling sebagai bahan utama bioplastik, minyak kelapa merk "Barco" sebagai minyak nabati untuk pembuatan monogliserida. Kedua bahan ini diperoleh dari pasar Semarang, Bahan lain yang dibutuhkan yaitu: gliserol, asam fosfat dan $\mathrm{NaOH}$ diperoleh dari laboratorium Akademi Kimia Industri St. Paulus Semarang.

\subsection{Alat}

Peralatan yang digunakan dalam penelitian ini meliputi: reaktor berupa labu leher tiga yang dilengkapi dengan kondensor (pendingin bola) dan pengaduk magnetic stirrer, hot plate sebagai alat pemanas, thermometer untuk mengukur temperatur, cawan petri untuk mencetak bioplastik, oven untuk pengeringan, neraca analitik, dan peralatan penunjang lain.

\subsection{Variabel Penelitian}

Sebagai variabel tetap meliputi: bahan baku, metode proses, kondisi proses, metode pengeringan bioplastik. Sedangkan sebagai variabel bebas, yaitu: penambahan monogliserida $(0 \% ; 1 \% ; 2 \% ; 3 \% ; 4 \% ; 5 \%)$. Variabel terikat untuk menunjukkan karakter bioplastik yang dihasilkan meliputi: densitas, ketebalan film, tensile strength dan elongation, serta morfologi permukaan film.

\subsection{Prosedur Penelitian}

Proses penelitian terdiri dari dua tahap, yaitu :

1) Pembuatan monogliserida.

Pembuatan monogliserida dilakukan dengan melarutkan katalis $\mathrm{NaOH}$ sebanyak $0,1 \%$ dari berat minyak (100 gram minyak kelapa) dalam gliserol (190 gram). Proses pelarutan dilakukan di dalam beacker glass pada temperatur $90^{\circ} \mathrm{C}$ dan diaduk secara manual. Kemudian memanaskan minyak kelapa sebanyak 100 gram sampai temperatur $150^{\circ} \mathrm{C}$ di dalam labu leher tiga. Selanjutnya ditambahkan larutan katalis $\mathrm{NaOH}$ dalam gliserol sedikit demi sedikit. Selama proses pencampuran tetap dilakukan pengadukan selama 1 jam, dan temperatur dipertahankan pada $150^{\circ} \mathrm{C}$. Kemudian temperatur dinaikkan hingga $200^{\circ} \mathrm{C}$ untuk proses reaksi pembentukan monogliserida. Reaksi ini dilakukan selama 3 jam dan disertai pengadukan. Hasil reaksi kemudian didinginkan hingga temperatur $100^{\circ} \mathrm{C}$, dan kemudian dilakukan deaktifasi katalis $\mathrm{NaOH}$ dengan penambahan asam fosfat hingga $\mathrm{pH}$ 
larutan netral. Monogliserida yang dihasilkan selanjutnya dipisahkan dengan menggunakan corong pisah.

2) Pembuatan bioplastik.

Kolang kaling dicuci bersih, kemudian dipotong kecil-kecil, kemudian dimasukkan ke dalam blender, dan ditambahkan aquades (1:1) untuk dihancurkan agar terbentuk bubur kolang-kaling. Sebanyak 30 gram bubur kolang kaling yang terbentuk dimasukkan ke dalam beaker glass, kemudian ditambahkan aquades hingga mencapai 100gr (70 gram aquades). Selanjutnya dipanaskan pada suhu $70^{\circ} \mathrm{C}$ hingga terjadi gelatinasi. Proses ini dilakukan dengan pengadukan menggunakan magnetic stirrer.

Bila telah terjadi gelatinasi, kemudian ditambahkan monogliserida sedikit demi sedikit sambil terus diaduk. Penambahan monogliserida sebanyak $0 \% ; 1 \% ; 2 \% ; 3 \%$; $4 \%$; dan $5 \%$ b/b. Proses pencampuran dilakukan selama 15 menit. Adonan yang telah terbentuk, selanjutnya didiamkan \pm 10 menit tanpa pemanasan tetapi tetap diaduk, untuk menghilangkan udara yang terperangkap dalam adonan (degassing process). Adonan ini kemudian dituangkan ke dalam cawan petri yang berdiameter $9 \mathrm{~cm}$, sebanyak 10 gram. Cawan petri yang berisi adonan bioplastik, selanjutnya dimasukkan ke dalam oven untuk proses pengeringan. Proses di oven berlangsung pada temperatur $55^{\circ} \mathrm{C}$ selama $10-12$ jam. Setelah kering, cawan petri yang berisi bioplastik, kemudian dipindahkan ke desikator. Setelah dingin, bioplastik diambil dan dimasukkan dalam wadah tertutup. Karakterisasi yang dilakukan meliputi: densitas, ketebalan, tensile strength dan elongation, serta morfologi permukaan film.

Uji ketebalan bioplastik dilakukan dengan cara memotong film bioplastik berukuran $2 \mathrm{~cm} \quad x \quad 1 \mathrm{~cm}$. Uji ketebalan dilakukan pada 4 tempat yang berbeda dari sampel bioplastik tersebut, menggunakan mikrometer yang memiliki ketelitian
0,0001 mm.. Kemudian hasil pengukuran dirata-rata sebagai hasil ketebalan film bioplastik.

Uji densitas bioplastik dilakukan dengan cara: sampel film bioplastik (ukuran $2 \mathrm{~cm} \mathrm{x}$ $1 \mathrm{~cm})$ yang telah diukur ketebalannya, kemudian dihitung volumenya (panjang $\mathrm{x}$ lebar $\mathrm{x}$ tebal). Selanjutnya sampel film bioplastik ditimbang. Perhitungan densitas sampel bioplastik menggunakan persamaan sebagai berikut:

Densitas $=\frac{\text { Massa film }}{(\text { panjang } x \text { lebar } x \text { tebal }) \text { film }}$

Uji tensile strength dan elongation bioplastik dilakukan di laboratorium di Unika Sugijopranoto, dengan menggunakan alat Imada Force Measurement tipe ZP-200N. Dengan mengikuti prosedur kerja alat maka akan didapatkan data untuk tensile strength dan elongation bioplastik Dari alat tersebut akan didapatkan data untuk gaya (force) yang diperlukan untuk memutuskan bioplastik, dan perpanjangan film bioplastik sampai putus. Persamaan yang digunakan untuk menghitung tensile strength dan elongation bioplastik:

Elongasi $(\%)=\frac{\text { Pertambahan Panjang }}{\text { Panjang mula }- \text { mula }} \times 100 \%$

Tensile strength $\left(\frac{\mathrm{N}}{\mathrm{cm}^{2}}\right)=\frac{\text { Gaya }(N)}{\text { Satuan Luas }\left(\mathrm{cm}^{2}\right)}$

Uji morfologi dilakukan untuk mengetahui permukaan bioplastik secara mikroskopis. Uji morfologi menggunakan mikroskop dengan perbesaran $400 \mathrm{X}$.

\section{HASIL DAN PEMBAHASAN}

Hasil penelitian pengaruh penambahan monogliserida terhadap ketebalan film bioplastik dan densitas bioplastik ditunjukkan pada gambar 1 dan 2 sebagai berikut 


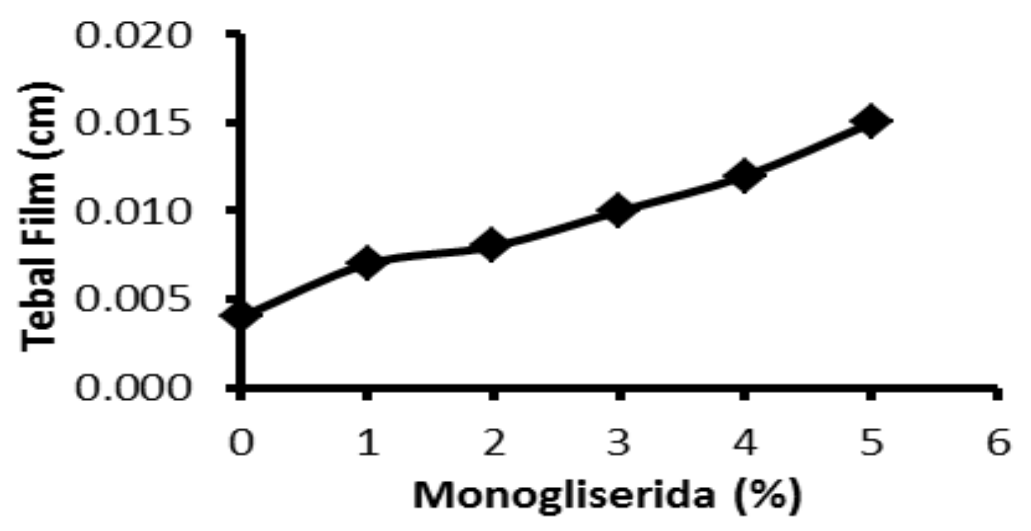

Gambar 1. Grafik hubungan penambahan monogliserida (\%) dengan ketebalan film bioplastik.

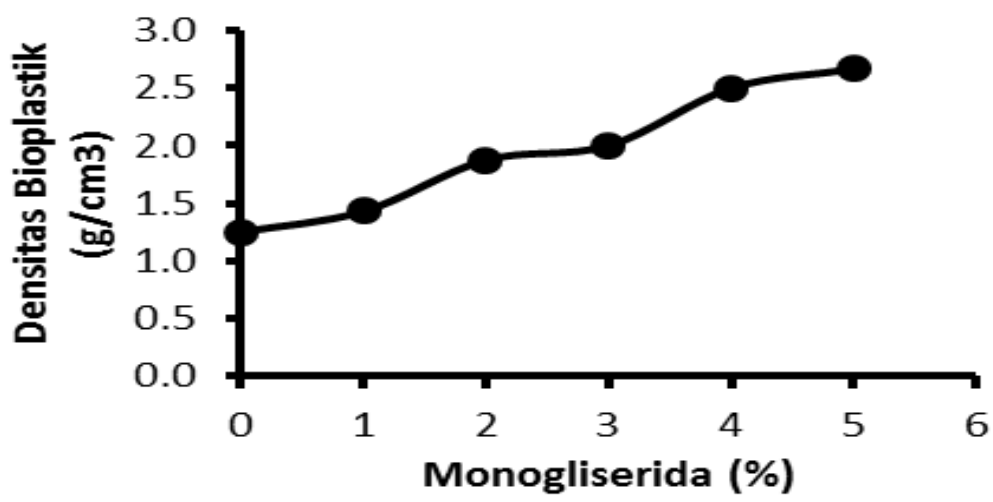

Gambar 2. Grafik hubungan penambahan monogliserida (\%) dengan densitas bioplastik.

Gambar 1 dan 2 menunjukkan bahwa ketebalan dan densitas bioplastik yang dihasilkan meningkat seiring banyaknya penambahan monogliserida. Hal ini disebabkan, semakin banyak monogliserida yang ditambahkan, akan membuat massa bioplastik bertambah, sehingga berpengaruh pada meningkatnya ketebalan dan densitas bioplastik yang dihasilkan. Hasil penelitian ini sesuai dengan pendapat Sumarto (2008), bahwa ketebalan film dipengaruhi oleh total padatan dalam larutan.

Pengaruh mogliserida terhadap tensile strength bioplastik dan elongation dapat dilihat pada gambar 3 dan 4 .

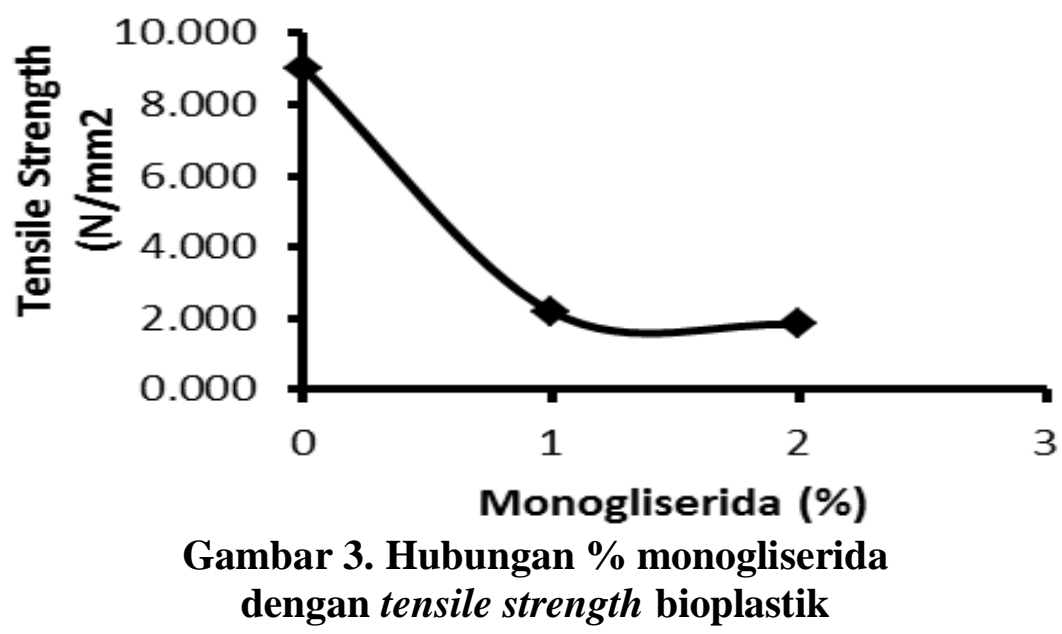




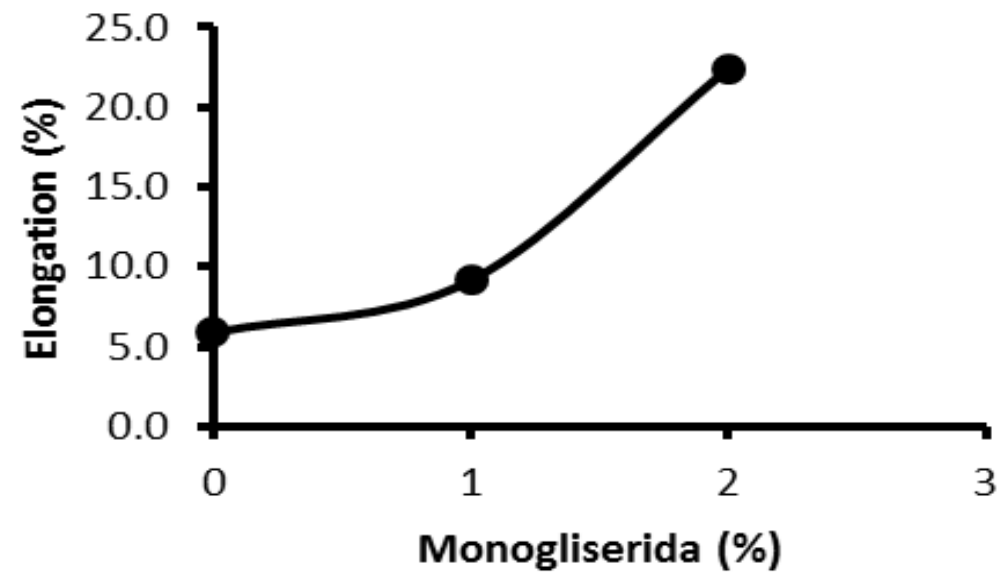

Gambar 4. Hubungan \% monogliserida dengan \% dengan elongation.

Gambar 3 menunjukkan bahwa penambahan monogliserida yang semakin banyak, menyebabkan tensile strength bioplastik justru semakin kecil. Sedangkan pada Gambar 4, semakin banyak monogliserida yang ditambahkan juga berdampak pada meningkatnya elongation.

Monogliserida yang digunakan dalam penelitian ini merupakan hasil reaksi alkoholisis atau transesterifikasi dari minyak kelapa dengan gliserol. Proses reaksi berkatalis ini dilakukan pada temperatur yang cukup tinggi, $200^{\circ} \mathrm{C}$ selama 3 jam disertai pengadukan. Meskipun demikian, reaksi tidak terjadi secara sempurna, sehingga hasil reaksi merupakan campuran, yaitu monogliserida sebagai hasil utama, digliserida sebagai hasil samping, dan sisa reaktan trigliserida serta gliserol. Menurut Juliati (2002), reaksi alkoholisis akan memberikan hasil campuran monogliserida, digliserida, trigliserida dan gliserol yang tidak bereaksi. Adanya kandungan sisa gliserol dan sisa trigliserida dalam monogliserida mampu meningkatkan fleksibilitas bioplastik, sehingga bioplastik yang dihasilkan menjadi lebih lunak. Dampaknya, ketahanan terhadap gaya tarik menurun atau bioplastik menjadi lebih mudah untuk ditarik (tingkat elongation meningkat).
Hasil uji morfologi ditunjukkan pada Gambar 5 sebagai berikut:

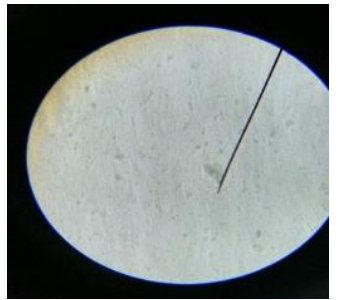

(a)

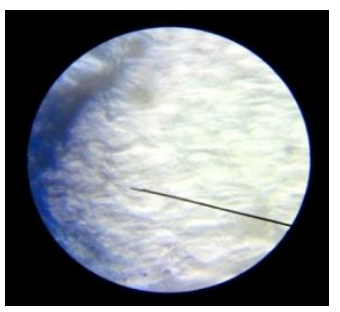

(c)

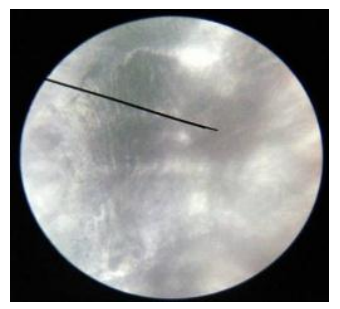

(e)

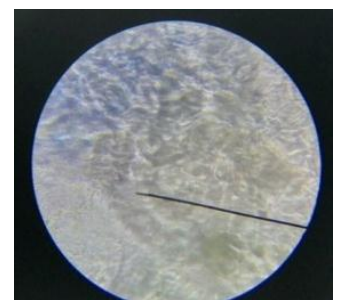

(b)

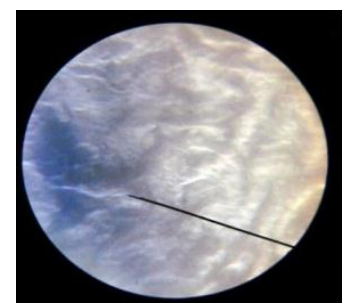

(d)

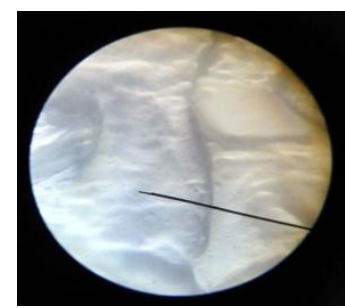

(f)
Gambar 5. Morfologi bioplastik: monogliserida (a) $0 \%$; (b) $1 \%$; (c) $2 \%$; (d) $3 \%$; (e) $4 \%$; dan (f) $5 \%$.

Morfologi bioplastik diamati menggunakan mikroskop dengan perbesaran 400 X. Gambar 5 menunjukkan bahwa penambahan monogliserida ternyata berpengaruh terhadap morfologi bioplastik hasil penelitian. Semakin banyak 
monogliserida yang ditambahkan, terlihat gelembung yang semakin besar dan bahkan menumpuk, sebaliknya semakin sedikit monogliserida terlihat gelembung yang kecil. Sedangkan yang tanpa penambahan monogliserida, tidak terlihat gelembung atau permukaan bioplastik terlihat halus.

Dari hasil analisa yang ditunjukkan pada Gambar 1 sampai dengan Gambar 5, ternyata ada korelasinya. Monogliserida yang ditambahkan pada pembuatan bioplastik dari kolang-kaling ini menyebabkan jarak penyusun bioplastik menjadi lebar, bahkan terjadi penumpukan (Gambar 5f). Hal ini menyebabkan bioplastik menjadi tebal, lunak (tensile strength menurun) dan mudah ditarik (elongation meningkat).

\section{KESIMPULAN}

Dari hasil penelitian dapat disimpulkan bahwa penambahan monogliserida dapat mempengaruhi karakteristik bioplastik yang dihasilkan. Penambahan monogliserida menyebabkan penambahan tebal, densitas, dan elongation bioplastik, tetapi menurunkan ketahanan (kekakuan) bioplastik.

\section{UCAPAN TERIMAKASIH}

Ucapan terimakasih kami sampaikan kepada Direktur Polteka Mangunwijaya dan Ketua LPPM atas dukungan dana dan fasilitas yang telah diberikan untuk pelaksanaan penelitian ini.

\section{DAFTAR PUSTAKA}

Danhowe, G. Dan O. Fennema., (1994), Edible film and Coating : Characteristic, formations, definitions and testing methods. $D i$ dalam Krochta et al., (Ed) Ediblecoating and Film to Improve Food Quality. Technomic Publ. Co. Inc. Lancaster.

Darni, Yuli, dan Herti Utami, (2010), Studi Pembuatan dan Karakteristik Mekanik dan Hidrofobisitas Bioplastik dari Pati Sorgum, Jurnal Rekayasa Kimia dan Lingkungan, Vol. 7, No. 4, ISSN. 1412-5064, p. 190-195.
Gennadios, A and C.L.Weller, (1990), Moisture Adsorption by grain Protein Films. Tranactions of ASAE, 37(2), 535-539.

Juliati, T. Br., (2002), Ester Asam Lemak, USU digital library, 1-13.

Lin, D, Y. Zhao, (2007), Innovations in the Development and Application of Edible Coatings for Fresh and Minimally Processed Fruits and Vegetables, Institude of Food Tecnologies. Wiegand Hall.

Mahmud Z, dan Amrizal, (1991), Palma Sebagai Bahan Pangan, Pakan dan Konservasi, Buletin Balitka, (14):106-113.

Sumarto, (2008), Mempelajari Pengaruh Penambahan Asam Lemak dan Natrium Benzoat terhadap Sifat Fisik, Mekanik dan Aktifitas Antimikroba Film Edible Kitosan, Skripsi Departemen Ilmu dan teknologi Pangan. Fakultas Teknologi Pertanian Institut Pertanian Bogor.

Syarief, R., dan A. Irawati, (1988), Pengetahuan Bahan untuk Industri Pertanian, Mediyatama Sarana Perkasa, Jakarta.

Winarno, F.G, (2002), Fisiologi Lepas Panen Produk Hortikultura, M_Brio Press. Bogor. Hal: 85. 